\title{
EARTHQUAKE HAZARD ANALYSIS OF NGANJUK REGENCY
}

\section{ANALISIS TINGKAT ANCAMAN BENCANA GEMPABUMI DI KABUPATEN NGANJUK}

\author{
Wisyanto ${ }^{1}$ dan Heru Sri Naryanto ${ }^{1}$ \\ ${ }^{1}$ Pusat Teknologi Reduksi Risiko Bencana - Badan Pengkajian dan Penerapan Teknologi, \\ JI. M. H. Thamrin No. 8, Jakarta 10340, \\ e-mail: wisyanto@bppt.go.id
}

\begin{abstract}
Earthquake hazard must be considered by many regions in Indonesia. This is including Nganjuk Regency, the area with intensifies development and where the longest dam in Indonesia is being built. Earthquake hazard studies are conducted using two methods, namely semi-deterministic and probabilistic methods. The results of analyses using the first method show that Nganjuk Regency can be divided into 3 classes of hazards, low level in the southwest region, middle level in the north and high level in the middle of the region. Analyses using the second method reveal that Nganjuk Regency can be classified into two categories, the southwest region which has the potential to experience very strong shocks with an intensity of upper VII MMI to lower VIII MMI and the northern and central region which has the potential of destructive shocks with an intensity of middle VIII MMI. The difference in the results from the two methods can be eliminated by classifying the detail of the existing soil/rock types.
\end{abstract}

Keywords: earthquake, hazard, semi-deterministic, probabilistic, Nganjuk Regency.

\begin{abstract}
Abstrak
Ancaman bencana gempabumi adalah masalah serius yang harus ditanggulangi oleh banyak daerah di Indonesia. Demikian juga dengan Kabupaten Nganjuk yang memiliki potensi besar dalam mengembangkan wilayahnya, terlebih dengan kehadiran sebuah bendungan terpanjang di Indonesia yang sedang dibangun. Studi ancaman gempabumi dilakukan dengan menggunakan dua metode, yaitu metode semi deterministik dan probabilistik. Hasil studi metode pertama menunjukkan bahwa Wilayah Nganjuk terbagi menjadi 3 kelas ancaman, ancaman tingkat rendah berada di wilayah barat daya, ancaman tingkat menengah di wilayah utara dan ancaman tingkat tinggi di wilayah tengah. Hasil studi metode kedua menunjukkan bahwa Wilayah Nganjuk terbagi menjadi dua, yaitu wilayah barat daya memiliki potensi untuk mengalami guncangan yang sangat kuat dengan intensitas VII MMI atas - VIII MMI bawah dan wilayah utara dan tengah berpotensi mengalami guncangan destruktif dengan intensitas VIII MMI tengah. Perbedaan hasil dari dua metode tersebut akan dapat diatasi dengan mengklasifikasikan jenis tanah / batuan yang ada secara lebih rinci.
\end{abstract}

Kata kunci: gempabumi, ancaman, semi deterministik, probabilistik, Kabupaten Nganjuk.

\section{PENDAHULUAN}

\subsection{Latar Belakang}

Ancaman gempabumi di Indonesia sudah menjadi berita yang umum bagi masyarakat Indonesia. Hal ini, selain karena seringnya peristiwa tersebut terjadi, juga karena banyaknya korban harta maupun benda di dalam setiap peristiwanya. Tingginya tingkat ancaman bencana gempabumi di Indonesia tidak terlepas dari adanya zona subduksi, dimana zona tersebut seringkali berdekatan dengan pusat-pusat permukiman. Bahkan tidak hanya terbatas pada daerah yang dekat dengan zona subduksi, ada juga jalur rawan gempabumi yang terletak cukup jauh dari zona subduksi, yaitu jalur yang relatif sejajar dengan zona subduksi dan sering berupa gempa-gempa pada kerak dangkal atau sebagai shallow crustal earthquake, seperti halnya gempa-gempa di sepanjang Sesar Baribis-Kendeng. Dalam melakukan kajian gempa, besaran gelombang gempa yang dipertimbangkan tidak terlepas dari proses atenuasi gelombang dari pusat gempa ke lokasi yang dikehendaki dan proses amplifikasi dari batuan dasar ke permukaan. Kedua hal inilah yang akan mempengaruhi respon spektral percepatan untuk desain 
bangunan di permukaan tanah. Adapun proses atenuasi ini dikelompokkan menjadi 3 , yaitu shallow crustal earthquake di tektonik aktif, shallow crustal di wilayah stabil/kontinen dan yang ketiga di wilayah subduksi (Abrahamson, 1997). Disisi lain, ground motion akan mengalami amplifikasi saat melewati media lapisan batuan sedimen, meskipun masih ada perdebatan antara ahli geoteknik dengan ahli geofisika pada percepatan tanah lemah dan yang kuat / weak and strong ground motion (Field, 1997).

Kabupaten Nganjuk salah satu pusat permukiman yang dekat dengan jalur Patahan Baribis-Kendeng. Kabupaten Nganjuk menarik untuk dikaji tingkat ancaman bencana gempanya, karena di daerah ini selain proses pembangunannya terjadi cukup pesat, juga sedang dibangunnya bendungan besar, yaitu Bendungan Semantok. Bendungan ini merupakan mega proyek dengan perkiraan anggaran sebesar 1,75 trilliun rupiah, serta merupakan bendungan terpanjang di Indonesia. Area bendungan memiliki luas sekitar 700 Hektar (Ha) dan mampu mengairi lahan pertanian $1.554 \mathrm{Ha}$ serta menghasilkan tenaga listrik sebesar 1,01 Megawatt (tribunnews.com). Dalam melakukan kajian fisik bangunan terhadap pengaruh gempabumi, dapat dilakukan dengan metode mikrotremor. Adapun kajian terhadap bangunan bendung lebih cocok memakai metode HVSR (Horizontal to Vertical Spectral Ratio) daripada FSR (Floor Spectral Ratio) (Wahyudin, 2019). Kabupaten Nganjuk sendiri sering dijuluki dengan kota angin, karena keberadaan anginnya yang cukup potensial, baik secara kontinuitas, durasi maupun intensitasnya, sehingga dapat dimanfaatkan sebagai sumber energi terbarukan (Wibowo, 2014), dengan syarat kecepatan angin harian minimumnya adalah $3,3 \mathrm{~m} / \mathrm{s}$ (Widyanto, 2018).

Untuk menentukan besar ancaman gempabumi pada suatu daerah dapat dilakukan dengan 2 cara, yaitu ditentukan dengan pendekatan deterministik atau dengan pendekatan probabilistik. Pendekatan deterministik (DSHA / Deterministic Seismic Hazard Analysis) dilakukan dengan skenario pengasumsian suatu kejadian gempa dengan besaran tertentu pada lokasi yang diinginkan, sedangkan pendekatan probabilistik (PSHA / Probabilitstic Seismic Hazard Analysis) adalah metode yang memperhitungkan dan menggabungkan ketidakpastian dari besaran, lokasi dan waktu kejadian gempa. Menurut Gürboğa (2013), pada DSHA, skenario gempabumi dievaluasi secara terpisah. Masing-masing sumber (patahan-patahan tunggal atau zona patahan-zona patahan) ditetapkan magnitudo, jarak sumber ke lokasi, tipe gerak dan pada beberapa kasus juga arah geraknya. Nilai percepatan tanah dari suatu skenario biasanya diperkirakan dengan menggunakan hubungan atenuasi, tetapi adakalanya dengan cara simulasi seismologis perpercepatan tanah. PSHA lebih rumit dibandingkan dengan DSHA, sering dipandang sebagai kotak hitam oleh praktisi. Oleh sebab inilah PSHA kurang dapat diandalkan dibandingkan dengan DSHA (Gürboğa, 2013). DSHA didasarkan pada kondisi geologis lapangan, sedangkan PSHA mengutamakan statistik gempa dan perhitungan numerik.

\subsection{Tujuan}

Tujuan dari penulisan makalah ini adalah untuk mengumpulkan semua parameter terkait dengan kegempaan di daerah studi untuk dianalisis sehingga didapatkan informasi mengenai tingkat ancaman gempabumi di Wilayah Kabupaten Nganjuk yang nantinya berguna sebagai dasar pengambilan keputusan untuk melakukan mitigasi bencana gempabuminya.

\section{BAHAN DAN METODE}

\subsection{Kondisi Umum Wilayah Nganjuk}

Kabupaten Nganjuk mempunyai luas wilayah $122.433,1 \mathrm{~km}^{2}$ dan terbagi menjadi 20 kecamatan dan 284 desa/kelurahan. Sebagian besar kecamatan berada pada dataran rendah dengan ketinggian antara 46 sampai dengan 95 meter di atas permukaan laut. Sedangkan 4 (empat) kecamatan yang berada pada daerah pegunungan terletak pada ketinggian 150 sampai dengan 750 meter di atas permukaan laut, dimana daerah tertingginya adalah Desa Ngliman di Kecamatan Sawahan. Wilayah Kabupaten Nganjuk memiliki kondisi dan struktur tanah yang cukup produktif untuk berbagai jenis tanaman. Kondisi dan struktur tanah yang produktif ini juga ditunjang dengan penyediaan air Kali Widas yang mengalir sepanjang $91 \mathrm{~km}$ dan mengairi daerah seluas $430 \mathrm{~km}^{2}$ dengan debit air $2643 \mathrm{~m}^{3} /$ detik (BPS, 2018). Proses pembanguan perkotaan di Nganjuk berlangsung cukup pesat, disamping itu juga sedang ada pembangunan bendungan sebagai proyek nasional, yaitu Bendungan Semantok (Gambar 1). Bendungan ini akan menjadi objek penting bagi kepentingan masyarakatnya dan sudah pasti harus mendapat perhatian juga dalam hal perlindungannya terhadap ancaman bencana gempabumi. 


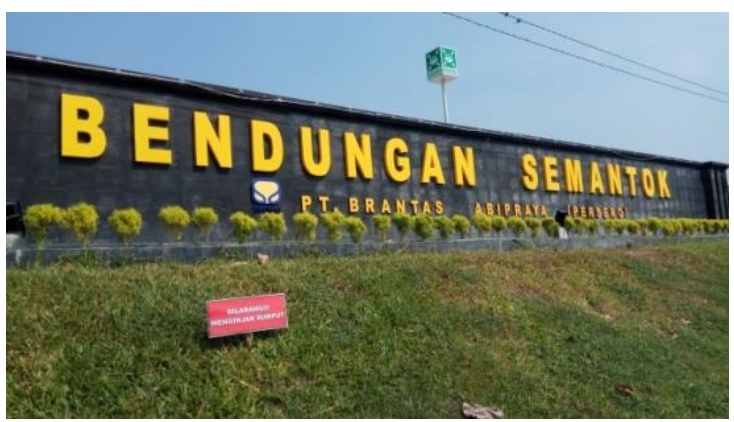

Gambar 1. Bendung Semantok yang merupakan waduk terpanjang di Indonesia.

\subsection{Patahan Yang Berkembang Kabupaten Nganjuk}

Wilayah Indonesia yang rawan terhadap gempabumi tidak terlepas dari kondisi tektoniknya yang sangat aktif. Tektonik di Indonesia dibagi menjadi dua sistem yang berbeda, yaitu di bagian barat Indonesia ditunjukkan dengan tumbukan tektonik antar Lempeng Samudera Hindia-Australia dan Lempeng Eurasia. Sementara di bagian timur Indonesia, kondisi tektoniknya dipengaruhi oleh adanya interaksi antara Lempeng HindiaAustralia, Pasifik dan Eurasia. Pertemuan gerak lempeng bumi ini ditunjukan oleh fenomena pembentukan jalur gempa, patahan aktif dan rangkaian gunungapi aktif atau sering disebut dengan volcanic arc. Daerah Nganjuk termasuk ke dalam bagian sistem tektonik Indonesia bagian barat.

Bila dilihat dari hubungan antara kondisi tektonik dengan kegempaannya atau sering disebut dengan istilah seismotektonik, kondisi Pulau Jawa dibagi menjadi 2 lajur seismotektonik, yaitu lajur seismotektonik tunjaman selatan Jawa dan lajur seismotektonik sesar aktif daratan Jawa. Berdasarkan morfologi kedalaman kegempaannya, lajur seismotektonik tunjaman Jawa terbagi menjadi 6 lajur (dari barat ke timur), sedang lajur seismotektonik sesar aktif daratan Jawa terdiri dari 14 lajur sesar aktif. $\mathrm{Ke} 14$ lajur seismotektonik sesar aktif ini adalah lajur seismotektonik sesar aktif Banten, Cimandiri, Citarik, Baribis, Citanduy, Bumiayu, Kebumen - Semarang - Jepara, Lasem, Rawapening, Opak, Pacitan, Wonogiri, Pasuruan, dan lajur seismotektonik sesar aktif Jember (Soehaimi, 2008).

Seiring dengan berkembangnya waktu dan teknologi, serta semakin meningkatnya kesadaran akan bahaya gempabumi, maka identifikasi sesar aktif di Pulau Jawa semakin gencar dilakukan, sehingga diperoleh hasilhasil pembaruan dalam identifikasi sesar aktifnya. Berikut adalah sebaran sesar aktif yang sudah dilakukan oleh Pusat Gempa Nasional yang bekerjasama dengan Kementerian Pekerjaan Umum dan Perumahan Rakyat (Kementerian PUPR) (Gambar 2). Pada gambar 2 terlihat sesarsesar aktif di seluruh Wilayah Pulau Jawa yang berhasil diidentifikasi sampai tahun 2017. Sesar aktif yang berada paling dekat dengan Kota Nganjuk adalah Sesar Aktif BaribisKendeng-Cepu dengan laju pergerakan segmennya sebesar $4,5 \mathrm{~mm} /$ tahun. Panjang sesar aktif ini adalah $106 \mathrm{~km}$ dan jarak terhadap Kota Nganjuk adalah 29 km. Sesar Aktif Baribis-Kendeng-Cepu ini berpotensi menjadi pusat gempa dimasa yang akan datang dan mungkin akan mengancam jiwa dan bangunan yang ada di Wilayah Nganjuk. Meskipun demikian, bila terjadi gempa yang diakibatkan oleh sesar aktif ini, bidang yang tersesarkan tidak seluruh panjang jalur sesar yaitu $106 \mathrm{~km}$ yang terlibat. Ada suatu perbandingan lurus antara Magnitudo gempa dengan dimensi bidang patahan dan jarak displacementnya. Pada tabel 1 terlihat daftar hubungan antara besar gempa dengan luas area yang mengalami displacement. Besar jarak pergerakan bidang displacement biasanya sebesar 1/20.000 dari panjang rupture. Misalkan gempa $4 \mathrm{Mw}$ dengan panjang rupture $1 \mathrm{~km}$, maka displacement yang terjadi $\pm 0,05 \mathrm{~m}$ (https://www.src.com.au).

Tabel 1. Hubungan antara besar gempa dengan luas area yang mengalami pergerakan (displacement) (https://www.src.com.)

\begin{tabular}{c|c|c}
\hline $\mathbf{( M w )}$ & $\begin{array}{c}\text { Luas Bidang } \\
\left.\text { Patahan } \mathbf{( k m}^{2}\right)\end{array}$ & $\begin{array}{c}\text { Dimensi Patahan } \\
(\mathbf{k m} \mathbf{~ x m})\end{array}$ \\
\hline 4 & 1 & $1 \times 1$ \\
\hline 5 & 10 & $3 \times 3$ \\
\hline 6 & 100 & $10 \times 10$ \\
\hline 7 & 1000 & $30 \times 30$ \\
\hline 8 & 10000 & $50 \times 200$ \\
\hline
\end{tabular}

Menurut Daryono (2019), Sesar Lembang di Jawa Barat yang membentang dari barat ke timur sepanjang $29 \mathrm{~km}$ berpotensi menimbulkan gempa dengan skala 6,5 -7 Mw. Bila dilihat dari laju pergerakan segmen seperti yang tercantum dalam Gambar 1, ternyata Sesar Lembang mempunyai laju 5 $\mathrm{mm}$ /tahun, sedangkan Sesar Baribis-KendengCepu mempunyai laju 4,5 mm/tahun, maka dengan mengabaikan berapa besar blok yang bergerak, mungkin Sesar Baribis-KendengCepu ini potensi magnitudonya lebih kecil dari Sesar Lembang, mungkin antara 5,5 -6,5 Mw. 


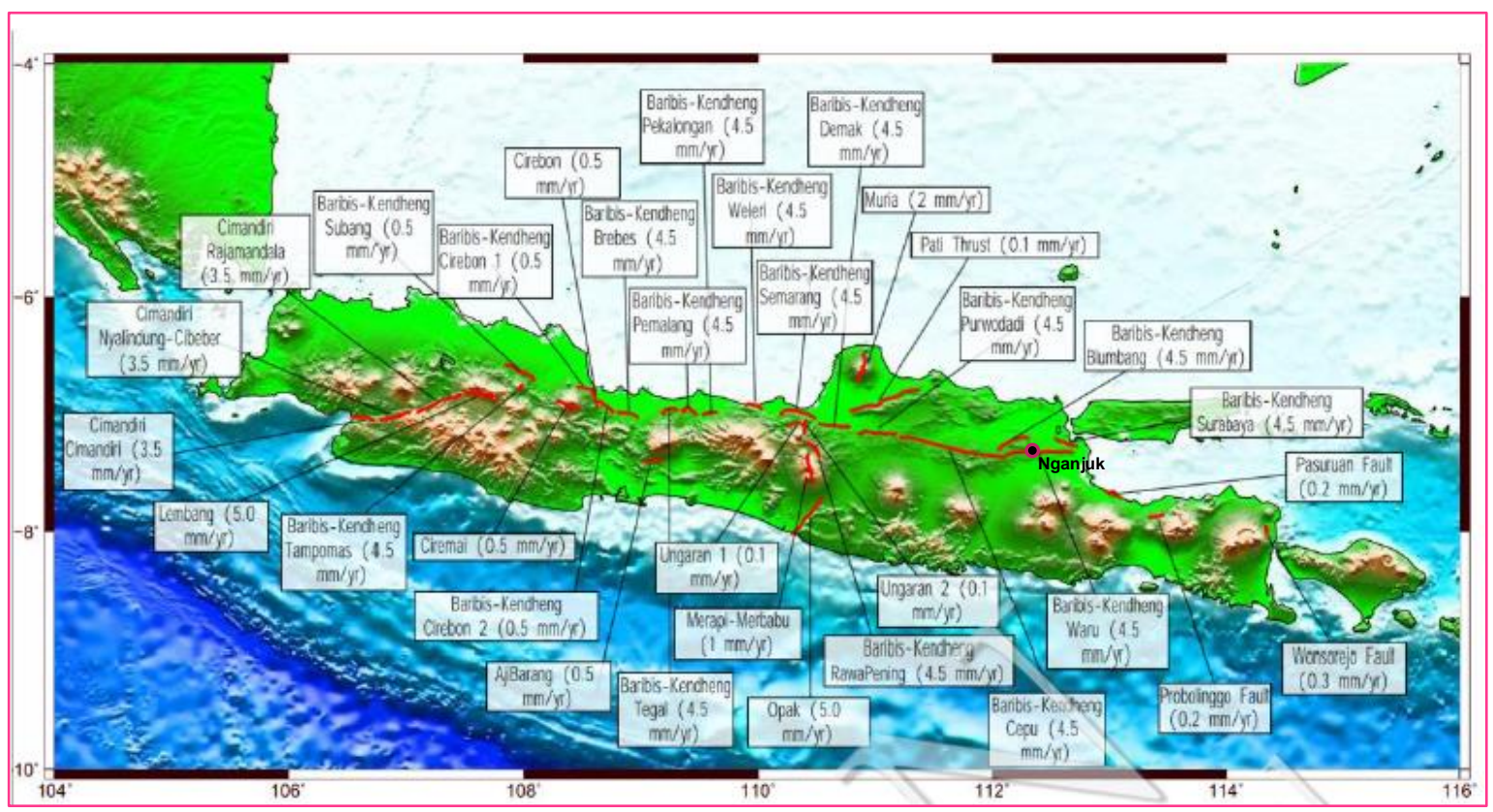

Gambar 2. Peta Sebaran Sesar Aktif di Indonesia (Pusgen, 2017).

\subsection{Kondisi Kegempaan di Nganjuk}

Tidak semua kejadian gempabumi dirasakan atau dicatat oleh suatu kelompok masyarakat. Hal ini sangat dimengerti, karena dampak yang dirasakan sangat terkait erat dengan besaran gempanya itu sendiri dan juga jarak dari episenter gempa. Terlebih dengan peristiwa gempa masa lampau, hanya lembaga pemantau saja yang mempunyai datanya secara lengkap, baik itu gempabumi yang dapat dirasakan masyarakat ataupun yang tidak terasa. Ada beberapa gempabumi yang dapat dirasakan oleh masyarakat Nganjuk dalam beberapa tahun terakhir ini.

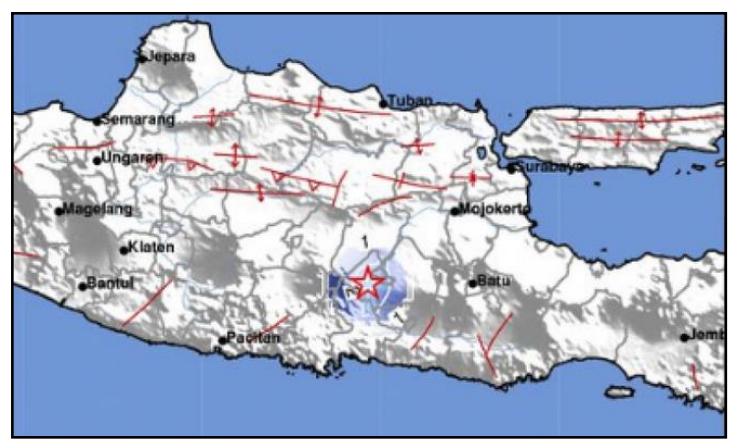

Gambar 3. Pusat Gempa Kediri yang terasa di Nganjuk dan tidak terpetakan (BMKG, 2019).

Gempa yang terjadi pada tanggal 19 Maret 2019 yang berpusat di Kediri, tepatnya disebelah timur Gunun. Ngliman atau $28 \mathrm{~km}$ sebelah selatan-barat daya dari Kota Nganjuk dengan magnitude gempa sebesar 3,5 Mw dan kedalaman 5 km (Gambar 3). Pusat gempa ini ternyata terjadi pada daerah yang bebas dari sesar aktif menurut peta sebaran sesar aktif Gambar 1). Jadi dapat dikatakan bahwa didaerah ini potensi gempanya belum terpetakan/teridentifikasi sebelumnya. Gempa yang berpusat di Kediri ini, terasa sampai Wilayah Nganjuk pada skala I-III MMI.

Gempa lain yang terjadi dan cukup mengagetkan masyarakat Jawa Timur adalah Gempa Situbondo. Gempa ini berpusat di laut tepatnya pada koordinat 114,44 Bujur Timur dan 7,46 Lintang Selatan atau $56 \mathrm{~km}$ timurlaut Situbondo (Gambar 4). Gempa dengan kekuatan $6 \mathrm{Mw}$ dengan kedalaman $12 \mathrm{~km}$ adalah termasuk dalam gempa kerak dangkal dan bukan gempa yang terdapat didalam tubuh lempeng (inner plate) yang menyusup ke bawah. Dampak dari gempa ini telah menelan 3 korban jiwa dan merusak cukup banyak bangunan di beberapa wilayah. Inilah bahayanya gempa dengan hiposenter dangkal, terlebih kalau dekat dengan objek yang terpapar. Seperti Gempa Situbondo yang terjadi pada tanggal 11 Oktober 2018 ini, walaupun jarak pusat gempa ke Kota Nganjuk $\pm 290 \mathrm{~km}$ akan tetapi telah mengejutkan masyarakat Nganjuk. Meskipun demikian dampak terhadap bangunan di Nganjuk tidak ada karena goncangan hanya pada intensitas I-III MMI. 


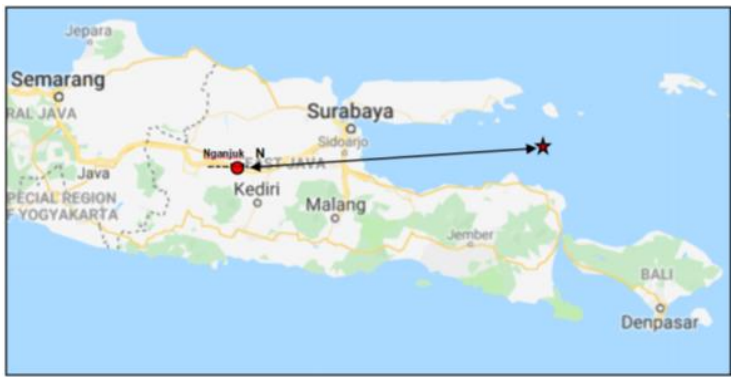

Gambar 4. Gempa Situbondo, 11 Oktober 2018, pusat gempa ke Nganjuk berjarak $290 \mathrm{~km}$.

Berdasarkan riwayat gempa yang terjadi di daerah Nganjuk dengan mengambil jari-jari $100 \mathrm{~km}$ dari pusat kota dan yang terjadi dari tahun 1900 sampai 2019, menunjukkan bahwa ada 186 gempa dengan magnitudo $>3$. Peristiwa gempa dengan skala yang lebih besar akan mempunyai frekuensi yang lebih kecil/sedikit, demikian halnya untuk sebaliknya. Pada luasan daerah yang sama seperti di atas, ternyata hanya terjadi 97 gempabumi untuk kejadian gempa dengan skala > 4,5 (Gambar $5)$. Dengan melihat sebaran gempa yang ada di daerah Nganjuk dan sekitarnya, ternyata sumber gempa terdapat di berbagai tempat, baik di bagian barat, timur, selatan maupun utara. Hal yang perlu diperhatikan adalah kedalaman dari gempabuminya, karena meskipun gempanya relatif kecil tetapi sangat dangkal dan dekat, maka gempa tersebut sudah berpotensi mengancam dan sebaliknya.

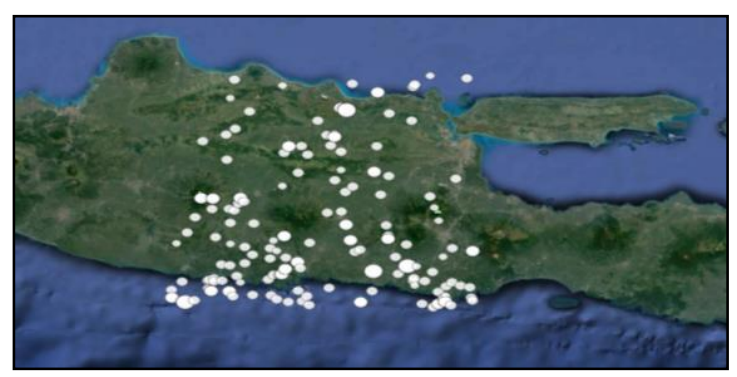

Gambar 5. Peta sebaran 97 episenter gempa M>4,5, pada rentang waktu 19002019 (https://earthquake.usgs. gov/earthquakes/map).

\subsection{Metode Penelitian}

Penentuan tingkat bahaya gempabumi dapat dilakukan melalui metode pendekatan deterministik atau dengan pendekatan probabilistik. Hal ini sangat bergantung pada data yang ada dan keperluannya. Pendekatan deterministik adalah suatu skenario dengan membuat asumsi suatu kejadian gempa dengan besaran tertentu pada lokasi tertentu, sedangkan pendekatan probabilistik merupakan metode yang memperhitungkan dan menggabungkan ketidakpastian dari besaran, lokasi dan waktu kejadian gempa. Metode deterministik mendasarkan pada kondisi geologis lapangan, sedangkan metode probabilistik mengutamakan pada statistik gempa dan perhitungan numerik. Mengingat tujuan daripada penelitian ini adalah untuk mengetahui tingkat ancaman gempa secara spasial di wilayah Nganjuk, maka data lapangan dan data sekunder yang diambil dan yang dipakai adalah data yang dapat dituangkan dalam format spasial. Dimana secara garis besar, metode yang dipakai ada dua, yaitu: semideterministik dan probabilistik.

- Metode semi deterministik yang dipakai disini, diawali dengan memanfaatkan data lapangan (struktur geologi dan litologi/endapan) dan data sekunder (peta geologi dan histori gempa), yang selanjutnya dianalisis melalui proses skoring dan pembobotan dan akan menghasilkan klas tingkat ancaman secara spasial.

- Metode probabilistik pada penelitian ini dilakukan dengan memanfaatkan data lapangan berupa jenis endapan dan batuan dan data sekunder berupa percepatan puncak di batuan dasar dengan nilai probabilitas terlampaui $2 \%$ dalam 50 tahun, mengikuti SNI 1726-2012 yaitu menggunakan gempa rencana, dimana umur struktur bangunan 50 tahun dengan probabilitas terlampaui $2 \%$. Selanjutnya dari nilai percepatan puncak di batuan dasar akan dicari nilai percepatan puncak di permukaan dengan memanfaatkan informasi jenis endapan dan litologi lapangan, yang kemudian ditentukan tingkat bahayanya secara spasial menurut klasifikasi USGS.

\section{HASIL DAN PEMBAHASAN}

Berbicara tentang bencana gempabumi, sangat erat kaitannya dengan goncangan yang ditimbulkannya. Karena dari goncangan inilah yang akan membawa dampak terhadap objek yang ada di permukaan tanah, baik itu manusia, bangunan permukiman, fasilitas umum bahkan sampai situs-situs peninggalan masa lampau. Besar goncangan gempabumi ini, selain dipengaruhi oleh besaran (magnitude) gempa dan jarak, juga dipengaruhi oleh lapisan batuan atau jenis endapan di bawah objek terpapar. Sehingga faktor batuan dan endapan sangat memegang 
peranan penting dalam menentukan tingkat ancaman gempabumi.

Wilayah Kabupaten Nganjuk, secara geologi di bagian selatan, ditempati oleh satuan-satuan batuan terobosan dan gunungapi dari Zaman Tersier dan endapanendapan Kuarter. Satuan tertua terdiri dari batuan Oligosen berupa terobosan andesit, dasit dan breksi gunungapi, di atasnya satuan dari kala Miosen berupa batupasir, tuf dan breksi gunungapi dari Formasi Jaten dan Wuni, dimana kedua formasi ini bersilang jari dengan satuan batugamping dari Formasi Wonosari, selanjutnya yang teratas adalah satuan batuan Kuarter yang terdiri satuan batuan terobosan andesit, lava andesit, aglomerat, breksi gunungapi, batupasir, tuf dan endapan alluvium. Endapan alluvium ini menempati daerah tengah dan dominan untuk Wilayah Nganjuk (Hartono et al, 1992). Sedangkan bagian utara satuan-satuan batuan dari Kala Miosen Tengah sampai Pliosen Atas berupa variasi lapisan batuan sedimen dengan perlapisan yang baik yang sangat berbeda dengan satuan batuan di sebelah selatan tadi yang didominasi oleh produk gunungapi. Bagian teratas ditempati oleh satuan batuan dan endapan Kuarter, termasuk endapan alluvium Holosen (Pringgoprawiro dan Sukido, 1992). Gambar 6 menunjukkan satuan-satuan batuan yang ada di wilayah Nganjuk, dimana wilayahnya didominasi oleh satuan endapan alluvium yang berada di bagian tengah yang terdiri dari pasir, kerakal, kerikil dan lumpur.

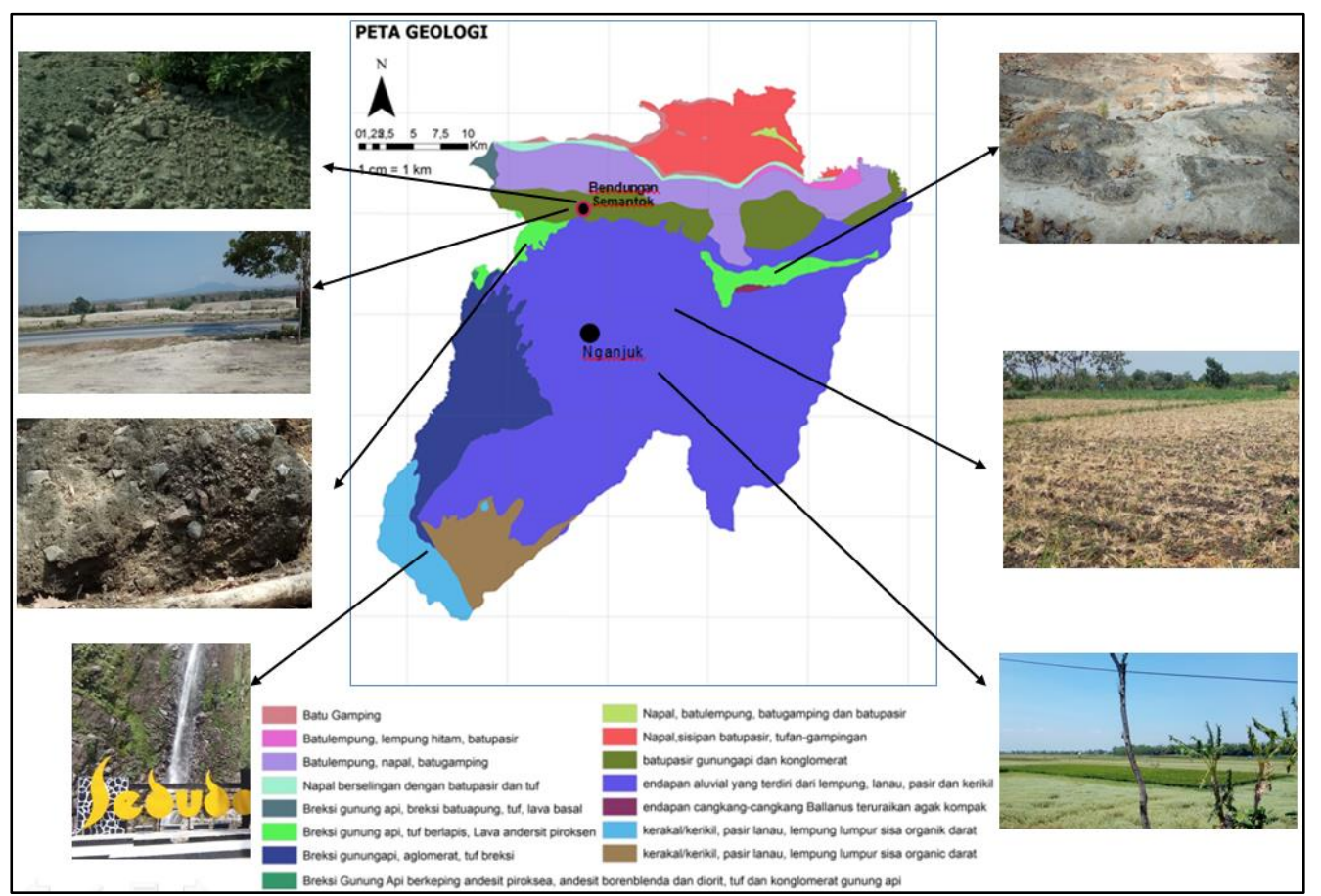

Gambar 6. Penyederhanaan satuan batuan yang ada di Kabupaten Nganjuk.

Dalam menentukan zona tingkat ancaman dengan metode skoring dan pembobotan, dipakai parameter batuan dan kegempaan. Untuk memudahkan proses skoring, tentang parameter batuan, satuan batuan yang tertera pada gambar 5 akan dikelompokkan menurut sifat atau yang menjadi faktor pembeda dalam merespon gelombang gempa yang datang. Maka penyederhanaannya menjadi kelompok batugamping dan breksi, kelompok batupasir, napal dan batulempung dan kelompok endapan. Pembagian ketiga kelompok ini dibuat berdasarkan nilai kekompakkannya, dimana urutannya tadi dimulai dari yang paling kompak (batugamping dan breksi) ke yang paling tidak kompak atau bahkan terurai / lepas, yaitu satuan endapan alluvium.

Parameter berikutnya adalah parameter gempa, dimana di dalamnya dibagi menjadi 3 , menurut besaran gempanya, kedalaman pusat gempa dan perimeter jarak gempa. Besaran gempa (magnitude) dibagi menjadi 3 kelompok besaran, yaitu: $M \leq 5,5 ; 5,5<M \leq 6$ dan $M>6$, selanjutnya dari setiap kelompok tersebut diperinci menjadi 2 kelompok menurut kedalaman gempanya (hiposenter), yaitu gempa dengan kedalaman $<60 \mathrm{~km}$ dan yang berkedalaman $>60 \mathrm{~km}$. Untuk perimeter jarak gempa dibagi menjadi 3 , yaitu $<30 \mathrm{~km} ; 30 \mathrm{~km}$ $60 \mathrm{~km}$ dan $>60 \mathrm{~km}$. Selanjutnya masalah penggunaan data gempa, data pusat gempa dipilih untuk gempa dengan skala $5 \mathrm{Mw}$ atau 
lebih yang terjadi dalam rentang waktu kejadian tahun 1900 sampai 2019 dan yang berada dalam radius lebih kurang $100 \mathrm{~km}$ dari pusat kota. Penelusuran data menunjukkan bahwa gempabumi dengan skala lebih dari 5 Mw, hanya ada 27 gempa (Gambar 7). Diantara ke 27 gempa ini, ternyata ada 4 gempa yang terjadi dalam skala $>6$, dimana yang terbesar ada 2 kejadian yaitu skala 6,6
Mb. Gempa yang terbesar ini, satu berada disebelah utara Kota Nganjuk dengan jarak 70 $\mathrm{km}$ dan yang lainnya ada di sebelah barat daya kota dengan jarak $87 \mathrm{~km}$. Gempa 6,6 yang di utara terjadi pada tahun 1950 pada kedalaman $45 \mathrm{~km}$, sedangkan gempa yang di sebelah barat daya Kota Nganjuk, terjadi pada tahun 28 September 1998 dengan kedalaman $151 \mathrm{~km}$.

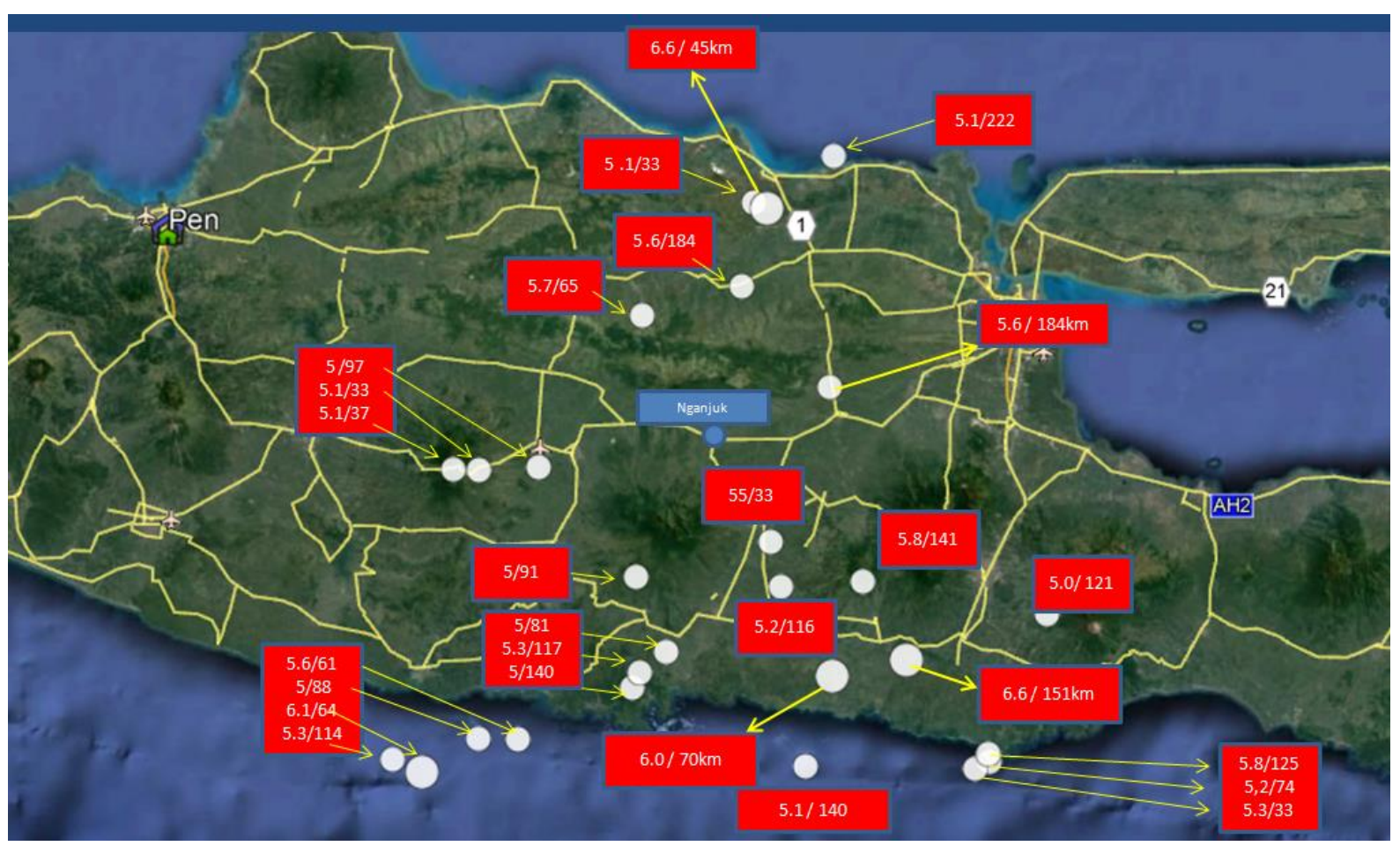

Gambar 7. Peta sebaran 27 gempa Magnitudo > $5 \mathrm{Mw}$ (keterangan dalam kotak merah: Magnitudo/kedalaman) pada selang waktu 1900 - 2019 (https://earthquake.usgs.gov/ earthquakes/map).

Selanjutnya dari semua data gempa yang ada, dibuat suatu pengelompokan (semi deterministik) menurut perkiraan kelompok sistem pensesaran yang berkembang. Akhirnya terklaster menjadi 4 kelompok. Kemudian dari setiap kelompok diambil 1 nilai yang paling berpengaruh, sehingga akan didapatkan 4 titik gempa perwakilan dari setiap klaster dan yang akan dimasukkan kedalam perhitungan. Akhirnya dengan memakai tahapan penilaian (skoring), normalisasi dan pembobotan telah dapat dibuat zona bahaya gempa di Kabupaten Nganjuk seperti pada Gambar 8. Hasilnya menunjukkan bahwa wilayah Kabupaten Nganjuk terbagi menjadi 3 zona tingkat ancaman, yaitu tingkat ancaman bencana gempabumi tingkat rendah yang berada di bagian barat daya dari Wilayah
Nganjuk dengan luas 27.414,98 (Ha), zona tingkat ancaman sedang yang berada dibagian utara dengan luas $31.484,72 \mathrm{Ha}$ dan tingkat ancaman tinggi yang berada dibagian tengah dengan luas 69.997,47 Ha. Bila melihat hasil pengklasifikasian tingkat ancaman bahaya gempabumi ini, Bendungan Semantok (Gambar 1) terletak pada zona ancaman bencana sedang. Meskipun terletak pada zona ancaman sedang, masih ada hal lain yang perlu diperhatikan lagi, yaitu bendungan ini berada cukup dekat $(17-20 \mathrm{~km})$ dari Sesar Aktif Baribis-Kendeng-Cepu. Sesar aktif ini berpotensi menimbulkan gempabumi dengan skala 5,5-6,5 Mw. Kondisi ini perlu diwaspadai, terlebih dengan kondisi geologisnya, dimana pondasi bendungan dominan berada pada endapan pasir lepas (Trenggana, 2019). 


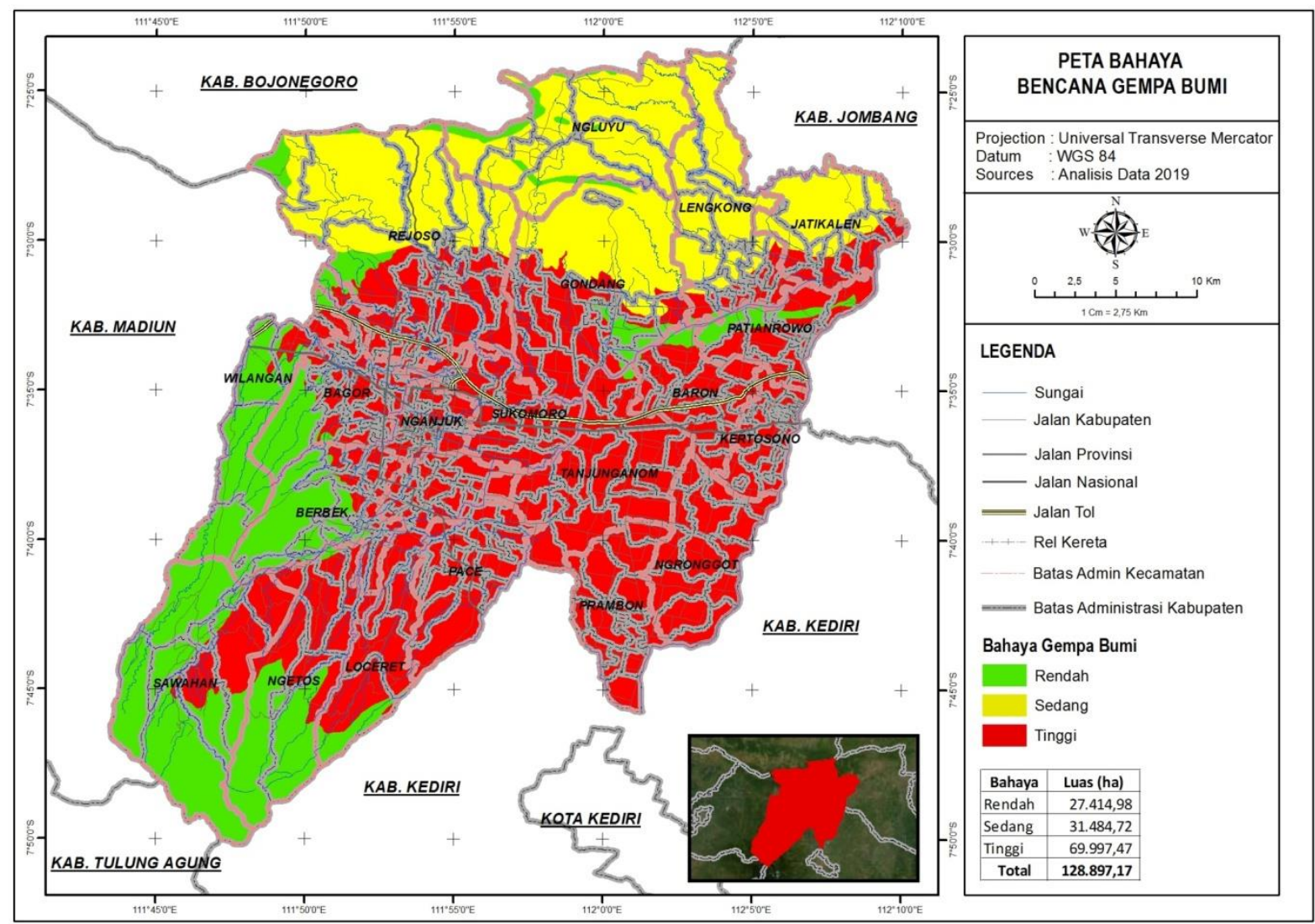

Gambar 8. Peta Zona Bahaya Gempa di Kabupaten Nganjuk dengan metode skor dan bobot.

Metode lain untuk menentukan tingkat ancaman gempabumi di Kabupaten Nganjuk ini adalah dengan metode probabilistik. Dalam mengantisipasi dampak bencana gempabumi, biasanya diacu peta bahaya yang diterbitkan oleh Kementerian PUPR. Peta bahaya yang dibuat dengan metode probabiltik ditampilkan dalam bentuk peta percepatan puncak pada batuan dasar. Peta terakhir yang dibuat oleh Kementerian PUPR adalah terbitan tahun 2017. Peta ini membagi bahaya menjadi 3 macam level hazard gempa, yaitu level hazard gempa 500 tahun, 1000 tahun dan 2500 tahun. Pada kajian bencana gempa di Kabupaten Nganjuk ini, akan dipakai peta percepatan puncak di batuan dasar dengan nilai probabilitas terlampaui $2 \%$ dalam 50 tahun, mengikuti SNI 1726-2012 yaitu menggunakan gempa rencana untuk umur struktur bangunan 50 tahun dengan probabilitas terlampaui $2 \%$ atau memakai potensi gempa dalam perioda ulang 2500 tahun / level hazard gempa 2500 tahun (BSN, 2012). Berdasarkan peta bahaya gempabumi dengan level hazard gempa 2500 tahun yang dibuat oleh Kementerian PUPR 2017 ini, menunjukkan bahwa Wilayah Kabupaten Nganjuk terbagi menjadi 2 zona nilai PGA, yaitu dibagian selatan mempunyai nilai PGA $0,3 \mathrm{~g}-0,4 \mathrm{~g}$ dan dibagian utara $0,4 \mathrm{~g}$ -
$0,5 \mathrm{~g}$ (Gambar 9). Sedangkan pada peta level hazard gempa 500 tahun, Wilayah Kabupaten Nganjuk hanya termasuk dalam satu zona, yaitu dengan nilai PGA $0,2 \mathrm{~g}-0,25 \mathrm{~g}$.

Penjalaran gelombang gempa sangat dipengaruhi oleh media yang dilewatinya. Pada Gambar 9 atau Gambar 10(a) besar percepatan tanah puncak yang ada adalah percepatan di batuan dasar. Untuk menentukan berapa besar percepatan di permukaan, harus diketahui besar faktor amplifikasi dari daerah yang dikaji. Satuan batuan yang mempengaruhi besar amplifikasi dibagi menjadi 6 jenis, yaitu batuan keras $\left(S_{A}\right)$, batuan $\left(S_{B}\right)$, tanah sangat padat dan batuan lunak $\left(\mathrm{S}_{\mathrm{C}}\right)$, tanah sedang $\left(\mathrm{S}_{\mathrm{D}}\right)$, tanah lunak $\left(S_{E}\right)$ dan tanah khusus $\left(S_{F}\right)$ seperti terlihat pada Tabel 2. Untuk menentukan besar percepatan tanah di permukaan, wilayah Nganjuk hanya dibagi menjadi 2 jenis satuan batuan, yaitu batuan $\left(S_{B}\right)$ yang menempati bagian utara dan barat daya Nganjuk dan satuan tanah sedang $\left(S_{D}\right.$ ) yang menempati bagian tengah. Untuk mendapatkan nilai percepatan tanah di permukaan, nila PGA di batuan dasar dikalikan dengan faktor amplifikasi menurut jenis batuan yang ada, sehingga untuk daerah yang disusun oleh tanah sedang, akan dikalikan dengan faktor 
amplifikasi 1,2 (Tabel 2). Melihat dari daftar nilai amplifikasi yang ada, maka nilai percepatan tanah di tanah sedang yang awalnya mempunyai nilai $0,3 \mathrm{~g}-0,4 \mathrm{~g}$ akan menjadi $0,36 \mathrm{~g}-0,48 \mathrm{~g}$, sedangkan untuk wilayah yang disusun oleh klasifikasi batuan $\left(\mathrm{S}_{\mathrm{B}}\right)$ akan mempunyai nilai tetap karena faktor amplifikasinya bernilai 1 .

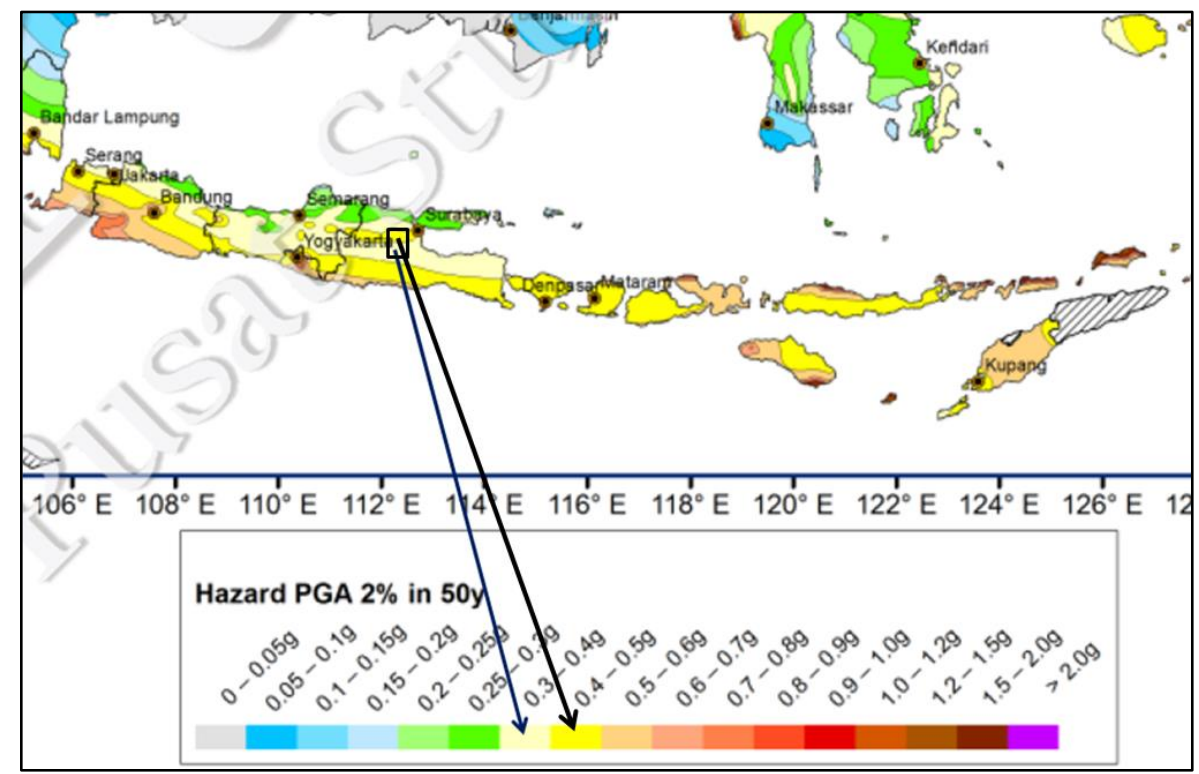

Gambar 9. Peta Percepatan Puncak Gempa denganprobilitas terlampaui 2\% dalam 50 tahun (Kementerian PUPR, 2017).

Tabel 2. Daftar faktor amplifikasi menurut jenis tanah/batuannya

(Kementerian PUPR, 2010).

\begin{tabular}{|l|c|c|c|c|c|}
\hline \multicolumn{1}{|c|}{$\begin{array}{c}\text { Klasifikasi Site } \\
\text { (Sesuai Tabel 2) }\end{array}$} & \multicolumn{5}{|c|}{ S $_{\text {PGA }}$} \\
\cline { 2 - 6 } & PGA 0.1 & $\mathrm{PGA}=0.2$ & $\mathrm{PGA}=0.3$ & $\mathrm{PGA}=0.4$ & $\mathrm{PGA} \geq 0.5$ \\
\hline Batuan Keras $\left(\mathrm{S}_{\mathrm{A}}\right)$ & 0.8 & 0.8 & 0.8 & 0.8 & 0.8 \\
\hline Batuan $\left(\mathrm{S}_{\mathrm{B}}\right.$ ) & 1.0 & 1.0 & 1.0 & 1.0 & 1.0 \\
\hline $\begin{array}{l}\text { Tanah Sangat Padat } \\
\text { dan Batuan Lunak }\left(\mathrm{S}_{\mathrm{C}}\right)\end{array}$ & 1.2 & 1.2 & 1.1 & 1.0 & 1.0 \\
\hline Tanah Sedang $\left(\mathrm{S}_{\mathrm{D}}\right)$ & 1.6 & 1.4 & 1.2 & 1.1 & 1.0 \\
\hline Tanah Lunak $\left(\mathrm{S}_{\mathrm{E}}\right)$ & 2.5 & 1.7 & 1.2 & 0.9 & 0.9 \\
\hline Tanah Khusus $\left(\mathrm{S}_{\mathrm{F}}\right)$ & $\mathrm{SS}$ & $\mathrm{SS}$ & $\mathrm{SS}$ & $\mathrm{SS}$ & $\mathrm{SS}$ \\
\hline
\end{tabular}

Berdasarkan dari perhitungan tersebut, akhirnya diketahui bahwa wilayah Nganjuk terbagi menjadi 3 rentang nilai PGA, yaitu rentang $P G A 0,3 g-0,4 g$ yang berada di bagian barat daya, rentang nilai PGA $0,36 \mathrm{~g}-0,48 \mathrm{~g}$ berada dibagian tengah dan rentang nilai $0,4 \mathrm{~g}$ $0,5 \mathrm{~g}$ yang berada dibagian utara. Nilai $P G A$ ini agak sulit untuk dibayangkan dalam pemikiran awam, untuk itu nilai ini akan dicari kesepadanannya dengan skala intensitas gempa MMI yang dapat dilihat pada Tabel 3 .

Tabel 3. Daftar nilai PGA dengan besaran skala MMI (Worden et al, 2012).

\begin{tabular}{|c|c|c|c|c|c|c|c|c|c|c|c|}
\hline $\begin{array}{l}\text { PERCEIVED } \\
\text { SHAKING }\end{array}$ & Not felt & Weak & Light & Moderate & Strong & Very stif & png & Pevel & e & Violent & Extreme \\
\hline $\begin{array}{l}\text { POTENTIAL } \\
\text { DAMAGE }\end{array}$ & none & none & none & Very light & Light & Moder & te & $\mathrm{Mdd} . / \mathrm{He}$ & avy & Heavy & Very Heavy \\
\hline PEAK ACC.(\%g) & $<0.05$ & 0.3 & 2.8 & 6.2 & 12 & 22 & & 40 & & 75 & $>139$ \\
\hline PEAK VEL.(cm/s) & $<0.02$ & 0.1 & 1.4 & 4.7 & 9.6 & 20 & & 41 & & 86 & $>178$ \\
\hline $\begin{array}{l}\text { INSTRUMENTAL } \\
\text { INTENSITY }\end{array}$ & I & II-III & IV & V & VI & VII & & VIII & & IX & $X+$ \\
\hline
\end{tabular}

Mengingat nilai rentang dari ketiga nilai yang ada tadi saling overlap, maka akan dibuat pengelompokkan menurut rentang terdekat, menjadi bagian barat daya yang bernilai $0,3 \mathrm{~g}$ $0,4 \mathrm{~g}(30 \% \mathrm{~g}-40 \% \mathrm{~g})$ diberi tanda kotak kuning di Tabel 3 dan bagian tengah dan utara disatukan sehingga bernilai $0,36 \mathrm{~g}-0,5 \mathrm{~g}$ (36\%g$50 \% \mathrm{~g}$ ) bertanda kotak merah. Kedua rentang nilai tersebut bila dilihat kesepadanannya dengan skala intensitas (MMI), menunjukkan bahwa wilayah barat daya akan masuk ke kotak kuning yang sepadan dengan nilai intensitas (MMI) VII bagian atas hingga VIII bagian bawah, sedangkan wilayah tengah dan utara masuk dalam kotak merah yang sepadan dengan nilai intensitas (MMI) VIII tengah, 
dapat dilihat pada Gambar 10(b). Dalam tabel klasifikasi yang sama, dapat dilihat bahwa skala VII MMI termasuk dalam goncangan sangat kuat (very strong) dengan potensi kerusakan menengah dan VIII MMI dengan goncangnya merusak (destructive) atau bergoncang hebat (severe) dengan potensi kerusakan menengah-berat. Bila dilihat dari tanda-tanda di lapangan, kejadian gempa yang termasuk dalam skala intensitas VII MMI, orang akan sulit berdiri, meja-kursi rusak, sedikit kerusakan pada bangunan yang dibangun dengan desain dan konstruksi bagus, kerusakan kecil-menengah untuk bangunan dengan struktur biasa dan terbangun baik, kerusakan cukup parah pada bangunan dengan struktur buruk, cerobong asap rusak dan goncangan dapat dirasakan oleh pengendara kendaraan, sedangkan VIII MMI, akan terjadi sedikit kerusakan pada bangunan dengan desain khusus, kerusakan cukup parah pada bangunan besar, serta runtuh sebagian, kerusakan besar pada bangunan-bangunan berstruktur buruk dan menimbulkan robohnya cerobong asap, pabrik, kolom-kolom bangunan dan monument, demikian juga dengan furnitur berat akan tergeser.

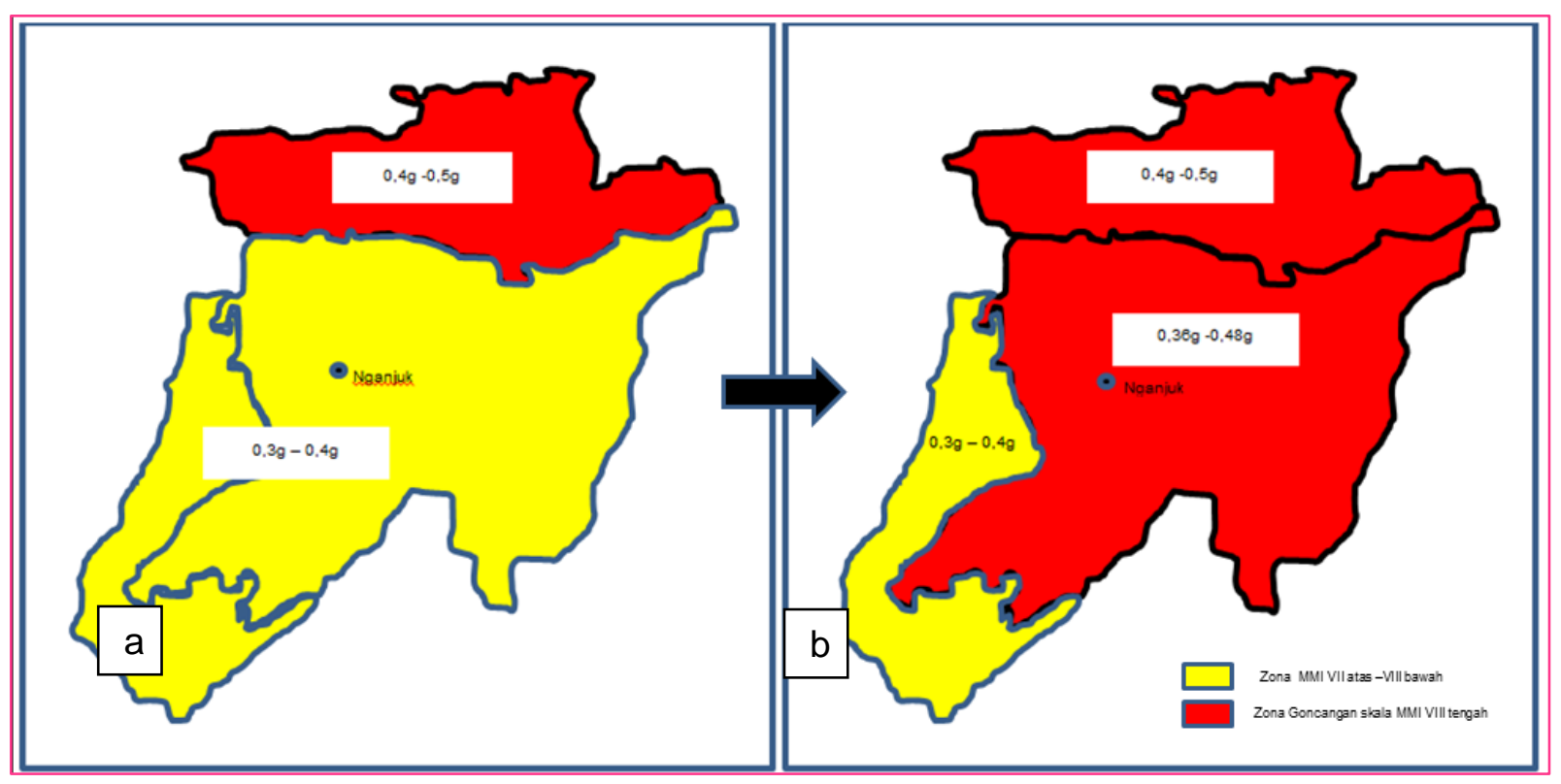

Gambar 10. Peta PGA di batuan dasar (a) Peta Ancaman Gempabumi dalam skala intensitas (b).

Hasil analisis terhadap tingkat ancaman bencana gempabumi di Kabupaten Nganjuk dengan dua metode yang berbeda (semi deterministic dan probabilistic), menunjukkan hasil yang sedikit berbeda. Dimana hasil analisis dengan metode semi deterministic menunjukkan bahwa wilayah Nganjuk terbagi menjadi 3 tingkat ancaman (Gambar 8), yaitu tingkat bahaya rendah (bagian barat daya), tingkat bahaya sedang (bagian utara) dan tingkat bahaya (bagian tengah), sedangkan hasil dari metode probabilistic, wilayah Nganjuk terbagi menjadi 2 tingkatan bahaya goncangan, yaitu goncangan dengan intensitas VII MMI atas sampai VIII MMI bawah (wilayah barat daya) dan VIII MMI tengah (Wilayah Nganjuk bagian atas dan tengah) (Gambar 10 b).

Perbedaan ini tidak terlepas dari perbedaan dasar pembagiannya, dimana metode pertama memakai klasifikasi relatif dari nilai indeks, menjadi rendah, sedang dan tinggi, sedang metode kedua memakai klasifikasi berdasarkan angka nyata (real bukan indeks). Perbedaan hasil dari kedua metode ini akan dapat diperbaiki melalui pendetailan klasifikasi jenis batuan / endapan yang ada di wilayah Nganjuk atau klasifikasi tingkat bahaya pada metode pertama dijadikan 2 klas tingkatan ancaman bencana.

\section{KESIMPULAN:}

- Dengan metode skor dan pembobotan, Wilayah Nganjuk terbagi menjadi 3 zona ancaman, yaitu ancaman tingkat rendah yang berada dibagian barat daya Wilayah Nganjuk dengan luas 27.414,98 $\mathrm{Ha}$, zona tingkat ancaman sedang yang berada dibagian utara dengan luas $31.484,72 \mathrm{Ha}$ dan tingkat ancaman tinggi yang berada dibagian tengah dengan luas 69.997,47 Ha.

- Bendungan Semantok terletak pada zona daerah tingkat ancaman bencana sedang. Meskipun demikian jarak 
bedungan dengan Patahan Aktif BaribisKendeng-Cepu hanya 17 - $20 \mathrm{~km}$ saja, sehingga perlu adanya upaya mitigasi di dalamnya. Terlebih dengan kondisi geologisnya, dimana pondasi bendungan dominan berada pada endapan pasir lepas.

- Perbedaan hasil dari metode pertama dan kedua dapat diperbaiki melalui pendetailan klasifikasi jenis batuan / endapan yang ada di wilayah Nganjuk atau klasifikasi tingkat bahaya pada metode pertama dijadikan 2 klas tingkatan ancaman bencana.

\section{DAFTAR PUSTAKA}

Abrahamson, N. A. and W. J. Silva. 1997. Empirical Response Spectral Attenuation Relations for Shallow Crustal Earthquakes. Seismological Research Letters (1997) 68 (1): 94127. https://doi.org/10.1785/gssrl.68. 1.94.

BMKG. (2019, 19 Maret 2019). Gempa Bumi Kediri-Nganjuk. Diakses pada 02/02/2020, dari pusat data https://twitter.com/infoBMKG.

BPS. 2018. Nganjuk Dalam Angka, Badan Statistik Kabupaten Nganjuk. 244 hal.

BSN. 2012. Tata Cara Perencanaan Ketahanan Gempa untuk Struktur Bangunan Gedung dan non Gedung. SNI: 1726-2012. Badan Standarisasi Nasional. 138 hal.

Daryono, M.R. 2019, Tekan Risiko Gempa Sesar Lembang, Pemda Harus Tegas soal IMB. https://jabar.sindonews. com/berita/6742/1/tekan-risiko-gempasesar-lembang-pemda-harus-tegassoal-imb.

Field, E.H., P.A. Johnson, I.A. Beresnev and Y. Zeng. 1997. Nonlinear Ground-Motion Amplification by Sediments During the $1994 \quad$ Northridge Earthquake. Nature volume 390, pages 599-602.

Gürboğa, Ş. and G. Sarp. 2013. Application of Deterministic Seismic Hazard Analysis On The Area Of 1970 Gediz Earthquake. International Journal of Engineering \& Applied Sciences (IJEAS) Vol.5, Issue 2, p. 18-37.

https://www.src.com.au/earthquake-size/

https://suryamalang.tribunnews.com/2016/02/2 6/wilayah-malang-tulungagung - dan nganjuk - juga - merasakan -gempa https://earthquake.usgs.gov/earthquakes/event s/1906calif/18april/reid.php)

https://earthquake.usgs.gov/earthquakes/map/ \#\%7B\%22feed\%22\%3A\%2215913481 $74173 \% 22 \% 2 \mathrm{C} \% 22$ sort\%22\%3A\%22n ewest $\% 22 \% 2 \mathrm{C} \% 22$ mapposition

Hartono, U., Baharuddin dan K. Brata. 1992. Peta Geologi Bersistem, Lembar Madiun. Pusat Penelitian dan Pengembangan Geologi.

Kementerian PUPR. 2010. Peta Hazard Gempa Indonesia 2010 sebagai acuan dasar perencanaan dan perancangan infrastruktur tahan gempa, Kementerian PUPR. 22 hal.

Pringgoprawiro, H. dan Sukido. 1992. Peta Geologi Bersistem, Lembar Bojonegoro. Pusat Penelitian dan Pengembangan Geologi.

Pusgen, Tim Pusat Studi Gempa Nasional. 2017. Peta Sumber dan Bahaya Gempa Indonesia tahun 2017, Pusat Penelitian dan Pengembangan Perumahan dan Permukiman, Kementerian PUPR.

Soehaimi, A. 2008. Seismotektonik dan Potensi Kegempaan Wilayah Jawa. Jurnal Geologi Indonesia, Vol. 3 No. 4: 227-240.

Trenggana, S.W. 2019. Pekerjaan Perbaikan Pondasi Pada Bendungan Semantok Dengan Metode Dinding Halang (Cut Off Wall). PT Brantas Abipraya (Persero) Jl. DI Panjaitan Kav 14, Cawang Jakarta Timur.

Wahyudin, Sulistiawaty dan I. Nasrul. 2019. Analisis Kerentanan Bendungan Ponre-Ponre Kabupaten Bone Berdasarkan Pengukuran Mikrotremor Dengan Metode HVSR. Jurnal Sains dan Pendidikan Fisika (JSPF) Jilid 15, Nomor 2. Hal: 90-96.

Widyanto, S. W., S. Wisnugroho dan M. Agus. 2018. Pemanfaatan Tenaga Angin Sebagai Pelapis Energi Surya Pada Pembangkit Listrik Tenaga Hibrid Di Pulau Wangi-Wangi. jurnal.umj.ac.id /index.php/semnastek Seminar Nasional Sains. Hal. 1-12.

Worden, C.B., M.C. Gerstenberger, D.A. Rhoades, D.J. and Wald (2012). Probabilistic relationships between ground-motion parameters and Modified Mercalli intensity in California Bull. Seism. Soc. Am. 102(1), 204-221. DOI: https://doi.org/10.1785/012011015. 